\title{
Essential elements of successful land development on Otago uplands
}

\author{
P. MACDOUGALL \\ Minzion Station, Millers Flat, RD Roxburgh
}

\section{Introduction}

In 1977 , we purchased a 1983 ha property carrying 1.5 $\mathrm{SU} / \mathrm{ha}(3000 \mathrm{SU})$ to develop it to carry $5 \mathrm{SU} / \mathrm{ha}(10,000$ $\mathrm{SU})$ finishing all stock. The property runs from 170 to $1000 \mathrm{~m}$ a.s.l. To achieve this large increase in stocking rate we:

- Used a combination of oversowing and cultivation to successfully establish pasture

- Topdressed with adequate rates of superphosphate and lime

- Changed to a more productive sheep breed

- Introduced a two tier cattle system to gain the advantages of cross-breeding

\section{Oversowing and cultivation}

On 1300 ha, oversowing was carried out as the first stage of development to enable large areas to be sown into pasture and grazed to initiate the soil fertility cycle. Coated white clover was sown at $5 \mathrm{~kg} /$ ha followed by a Ruanui ryegrass/Apanui cocksfoot mix in Year 3. The delayed sowing of grasses increased the establishment of both clovers and grasses. From 10 to 25 years after oversowing, 350 ha of this area were cultivated. This land was cultivated and sown into short rotation grasses and 3 years later, resown with a swede/turnip mixture in Year 1, kale in Year 2 and permanent pasture in Year 3. Brassicas were sown to provide winter feed and smooth out the surface of the paddock.

Six hundred hectares of the easiest country with broad, flat spurs and covered in standing dead large manuka was cleared by hand pulling and stick picking. It was then ploughed and sown using the same programme as the oversown country. Brassica seed was flown on to some of the blocks where manuka sticks and snowgrass bulbs were still present. This allowed us to winter hoggets on brassicas and put the blade shorn ewes on the crop after July. The oversown pasture was then able to come away for ewes at lambing.

\section{Fertiliser and lime}

On his first visit to the farm, my SouthFert field officer, the late Bill Parmenter, advised me to sow as much super and lime as I could afford. Nearly 30 years on, the rules are still the same. On the oversown country with average Olsen phosphorus of $9,375 \mathrm{~kg} / \mathrm{ha}$ of half strength moly superphosphate was applied in the spring with the clover seed. In the autumn, a further $250 \mathrm{~kg} / \mathrm{ha}$ of super was applied. Two hundred and fifty kilograms of super per hectare was applied in the spring of Years 2 and 3. From then on the oversown country has received $250 \mathrm{~kg} / \mathrm{ha}$ every second year.

The swedes/turnips cultivated country got $250 \mathrm{~kg} / \mathrm{ha}$ of half strength moly serpentine super flown on with the seed. At the same time $250 \mathrm{~kg} /$ ha of triple super containing boron was also flown on. The same fertiliser mix was used in subsequent years with $250 \mathrm{~kg} / \mathrm{ha}$ of serpentine super applied at sowing into permanent pasture.

On the oversown country with soil $\mathrm{pH} 4.5-5.1$ in Years 3 and 5, we flew on $250 \mathrm{~kg} / \mathrm{ha}$ of lime with the super. The cultivated country received 2.5 tonnes of lime per hectare by truck after ploughing and a further $2.5 \mathrm{t} /$ ha when the permanent pasture was sown. When the grass paddocks go back through the brassica/new pasture cycle every 10 years the lime applications are repeated.

All brassica crops have received $100 \mathrm{~kg} / \mathrm{ha}$ of urea in February when the plants are 3 months old.

\section{Change of sheep breed}

We changed breeds from half breds to Perendales to increase lambing percentage and wool weights. More productive sheep were required to make best use of the newly developed productive pasture. Our Perendales lamb at $130-140 \%$ with $25 \%$ of the lambs drafted off their mothers and all lambs killed at $17-18 \mathrm{~kg}$.

\section{Two tier cattle system}

We run a base herd of horned Herefords mated to Hereford and Angus bulls and a herd of Angus/Hereford first cross cows mated to Charolais bulls. With the cross bred cows, we gain hybrid vigour from the three crosses. Calving percentage ranges from $90-95 \%$ with heifers killed at $220-240 \mathrm{~kg}$ at 24 months and steers at 30 months at $300-370 \mathrm{~kg}$.

With the increase in stock numbers, we now topdress the calving blocks with $250 \mathrm{~kg} / \mathrm{ha}$ of Pasture Zeal (superphosphate and urea $(3 \% \mathrm{~N})$ with added copper (5 $\mathrm{kg} / \mathrm{ha}$ of copper sulphate) and selenium (1 kg/ha of prills).

In conclusion if I was asked how I would go about developing a hill block again, in my opinion this is a successful recipe which has stood the test of time and has allowed us to substantially grow our farming business.

I acknowledge the support of my family in our farming enterprise. 